\title{
Budd-Chiari Syndrome: Aetiologi, Diagnosis, and Management
}

\author{
Gunady Wibowo R, Hirlan \\ Division of Gastroentero-hepatology, Department of Internal Medicine \\ Universitas Diponegoro/Dr. Kariadi General Hospital, Semarang
}

\begin{abstract}
Corresponding author:
Hirlan. Division of Gastroentero-hepatology, Department of Internal Medicine, Universitas Diponegoro/Dr Kariadi General Hospital. Jl. DR. Sutomo No. 16 Semarang Indonesia. Phonelfacsimile: +62-24-8413476. E-mail: gastro_semarang@yahoo.com
\end{abstract}

\begin{abstract}
Budd-Chiari syndrome (BCS) is known as a disease caused by the presence of outflow obstruction of the hepatic vein and is commonly not considered as a diagnosis. Such obstruction may happen in all hepatic vein flow points, starting from small veins to the inferior vena cava opening in the right atrium, regardless of the aetiology. This syndrome occurs in approximately $0.001 \%$ population and has various aetiologies, including congenital and acquired prothrombotic conditions, myeloproliferative disease, and oral contraceptives use. Advancement in imaging enables most BCS to be diagnosed based on non-invasive imaging tests. Colour Doppler ultrasonography, which has sensitivity and specificity rate of $85-95 \%$, is an appropriate technique for early investigation of Budd-Chiari syndrome. Colour Doppler ultrasonography and multi-slice computed tomography (MSCT) with contrast have a significancy rate of $85-91.3 \%$ with a $p$ value $>0.05$ between both modalities in diagnosing BCS. Management of BCS starts with the non-invasive to highly invasive procedures, consisting of medical or recanalization therapy to prevent necrosis.
\end{abstract}

Keywords: Budd-Chiari syndrome, aetiology, radiology, recanalization

\begin{abstract}
ABSTRAK
Sindrom Budd-Chiari (BCS) dikenal dengan penyakit akibat adanya obstruksi outflow vena hepatika dan sering tidak terpikirkan sebagai sebuah diagnosis. Obstruksi tersebut dapat terjadi pada semua titik pada aliran vena hepatika. Mulai dari vena-vena kecil hingga ostium vena cava inferior di atrium kanan, tanpa mempersoalkan penyebabnya. Sindrom ini terjadi pada sekitar $0.001 \%$ populasi dan memiliki beragam potensi etiologi, termasuk kondisi protrombotik bawaan dan didapat, penyakit mieloproliferatif, dan penggunaan kontrasepsi oral. Kemajuan dibidang imaging, menyebabkan sebagian besar BCS dapat ditegakkan diagnosisnya berdasarkan pemeriksaan non-invasive imaging. Ultrasonografi Colour Doppler yang memiliki sensitivitas dan spesifisitas 85-95\% adalah teknik yang tepat untuk investigasi awal sindrom Budd-Chiari. Ultrasonografi Colour Doppler dan multi-slice computed tomography (MSCT) menggunakan kontras memiliki nilai signifikansi 85-91,3\% dengan nilai $p>$ 0.05 antara keduanya dalam mendiagnosis BCS. Pengelolaan penyakit BCS dimulai dari tindakan yang tidak invasif hingga tindakan yang sangat invasif, yang terdiri dari terapi medik atau rekanalisasi untuk mencegah nekrosis.
\end{abstract}

Kata kunci: Sindrom Budd-Chiari, etiologi, radiologi, rekanalisasi 


\section{INTRODUCTION}

Liver vascular disorder, although affecting less than 5/10000 patients, may become the aetiology of a number of rare conditions which represent significant health problems in the field of liver disease worldwide. The common characteristic in most of these disorders is that this disease may cause non-cirrhosis portal hypertension with high morbidity and mortality. The progress in knowledge of liver vascular disorders is impeded by the small number of cases and studies which evaluated the natural disease progressions, pathophysiology or therapy. ${ }^{1}$

Currently, Budd-Chiari syndrome (BCS) is known as a disease caused by the obstruction of hepatic vein outflows. This obstruction may occur in all hepatic vein flow points, beginning from the small veins to the opening of inferior vena cava in the right atrium, irrespective of the aetiology. BCS is a rare disease. This syndrome appears in approximately $0.001 \%$ of the population and has various aetiologies, including congenital and acquired prothrombotic conditions, myeloproliferative disease, and oral contraceptive use. Improvement in imaging techniques permits most $\mathrm{BCS}$ to be diagnosed using non-invasive imaging examinations. Colour Doppler ultrasonography which has sensitivity and specificity rate of $85-95 \%$ is an appropriate technique to initially investigate BuddChiari syndrome. Colour Doppler ultrasonogtaphy and MSCT with contrast have a significancy rate of 85$91.3 \%$ with a $p$ value $>0.05$ between both modalities in diagnosing BCS. Most obstruction in the hepatic vein outflow is caused by intraluminal obstructions, particularly hepatic vein and/or inferior vena cava thromboses. This type of BCS is considered as primary BCS, whereas secondary BCS ensues as a result of extraluminal compressions, such as due to tumor, abcess, or cyst. ${ }^{2}$

Budd-Chiari syndrome is not commonly considered as a primary diagnosis, and usually the presence of abnormal result in liver function test may be misevaluated as hepatitis. Patient is commonly diagnosed with cholestitis due to the combination of abdominal pain and ultrasonography examination showing the thickening of bile duct wall. Finally, many investigations are commonly performed to determine the cause of ascites and definitive therapy may be delayed. Therefore, it is important to consider the diagnosis of Budd-Chiari syndrome in all patients with clinical symptoms such as: (1) Abdominal pain, hepatomegaly, and ascites with progressive deterioration; (2) massive ascites with slight changes in liver function test; (3) fulminant liver failure with hepatomegaly and ascites; (4) chronic liver disease with indeterminate causes; (5) liver diseases with thrombogenic disease features. ${ }^{1,2,3}$

\section{PATHOGENESIS}

Hepatic vein obstruction triggers increased sinusoidal pressure, hepatomegaly, upper right abdominal pain and portal hypertension. Severe obstruction occurs when all outflows from hepatic vein are obstructed, resulting in increased sinusoidal pressure that may decrease perfusion, causing perisinusoidal necrosis which started from zone 3 and may result in liver failure. Necrosis which happens is an ischemic necrosis and may stimulate the oxidative stress process and free radical release. This will further cause the necrosis to expand and become fulminant. In the caudate lobe, the drainage immediately ends in inferior vena cava that may compensate the obstructed vein and cause hypertrophy of the caudate lobe. Collateral is an important clinical feature. Collaterals in the abdominal wall may occur around the umbilicus along the obstructed hepatic vein. The collateral is a sign of portal hypertension. BCS can be classified into acute $(26 \%)$, chronic $(20 \%)$, and superimposed acute on chronic $(50 \%)$.

\section{AETIOLOGY}

Factors which may predispose to the development of Budd-Chiari syndrome include hypercoagulable states, either hereditary or congenital and acquired and other aetiologies, can be identified in approximately $75 \%$ patients. Haematological abnormalities, particularly myeloproliferative disorder, are the most common causes in Budd-Chiari syndrome. Polycytemia vera contributes to $10-40 \%$ of all cases in this syndrome, while essential thrombocytopenia and myelofibrosis are usually rare. The development of erythroid endogens which can be seen in $87 \%$ patient suspected to suffer from idiopathic Budd-Chiari syndrome shows that in majority of patients, where the aetiology of Budd-Chiari syndrome is unclear, actually had myeloproliferative disorder. ${ }^{5}$

Other aetiologies of this syndrome are paroxysmal nocturnal haemoglobinuria, antiphospholipid syndrome, and acquired protein $\mathrm{C}$, protein $\mathrm{S}$, and anti-thrombin deficiency. In some patients with Budd-Chiari syndrome, protein $\mathrm{C}$ deficiency is also associated with myeloproliferative disorder. Low levels of protein $\mathrm{C}$, protein $\mathrm{S}$, and antithrombin III are also 
linked to the presence of acute thrombus and in patients with liver disease, including Budd-Chiari syndrome. Factor V Leiden mutation, prothrombin gene mutation, and methylentetrahydropholate reductase mutation have also been documented in Budd-Chiari syndrome patients. Although some of these mutations can be found, the presence of only one mutation, might not be a predisposing factor to hepatic vein thrombosis as association to any of them with other predisposing factors may also lead to Budd-Chiari syndrome. .,5,6 $^{4}$

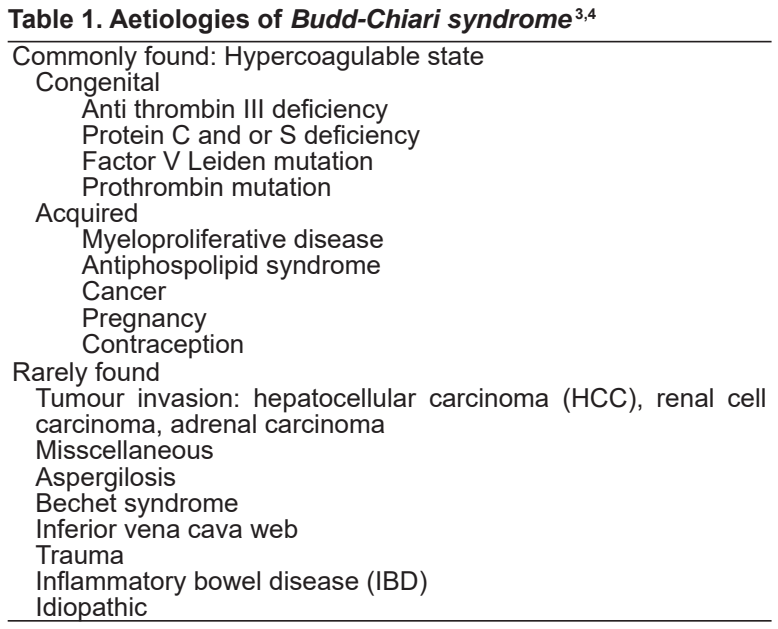

\section{Other Aetiological Factors}

Paroxysmal nocturnal haemoglobinuria (PNH) is an acquired chronic disorder which is marked by the presence of intravascular haemolysis and haemoglobinuria that usually occurs in patients during sleep at night. It is caused by cellular disorder due to somatic mutation in pluripotent haematopoietic stem cells leading to intrinsic damage in erythrocyte membrane causing it to be more prone to lysis from complement. This may also result in thrombocytopenia,

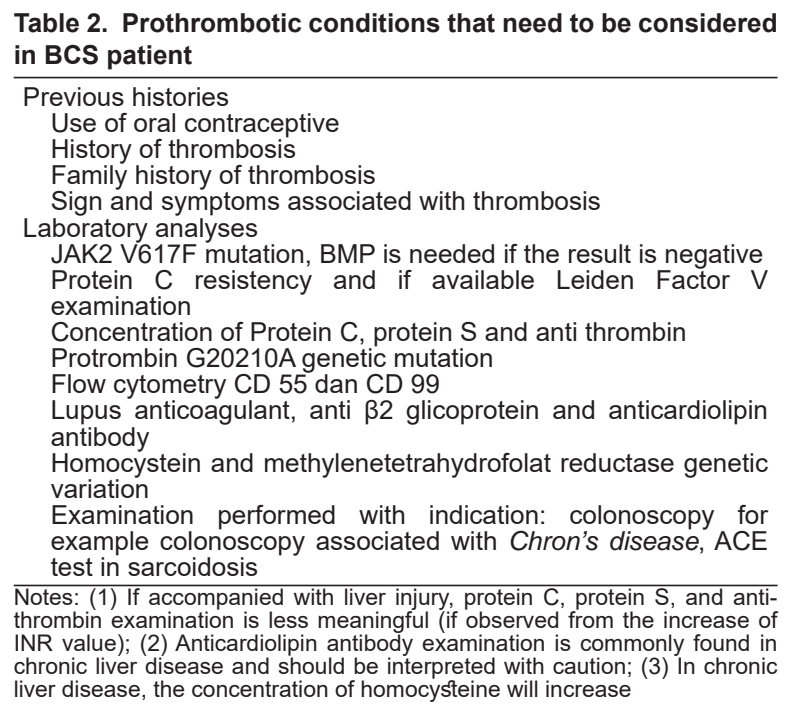

leukopenia, and vein thrombosis emergency. PNH has been reported in 9-19\% BCS patients. Evaluation of $\mathrm{PNH}$ should be performed routinely in patients with BCS. ${ }^{3,7}$

Hormonal factors, including the use of oral contraceptives and pregnancy, are considered as risk factors for BCS. Oral contraceptive has been associated with at least 2-fold increased risk of BCS. . $^{3,46}$

\section{DIAGNOSIS OF BUDD-CHIARI SYNDROME}

The important step in establishing the diagnosis is to consider the BCS diagnosis in patients who experienced sign or symptoms, such as liver enlargement with excruciating pain or the development of sudden or refractory ascites. The diagnosis of BCS also needs to be considered in acute or chronic liver disease with prothrombotic condition with unknown cause. The diagnosis of BCS is based on the findings of obstruction in hepatic vein outflows. This obstruction can be observed accurately through non-invasive imaging such as Doppler ultrasonography, computed tomography (CT) or magnetic resonance imaging (MRI). Doppler ultrasonography is considered as an initial choice of investigation that has high sensitivity and specificity. ${ }^{3-8}$

Proper identification in sonography is associated with related pathological or invasive imaging findings as well. Doppler USG and MRI are efficient imaging modalities in defining hepatic vein outflow obstruction with a significancy rate of $85-91.3 \%$ with $\mathrm{p}>0.05$. Standard laboratory analysis such as routine blood examination, blood chemistry, liver function test, kidney function test and International normalized ratio (INR), although provide little information in diagnosing BCS, are very helpful in determining the severity of the disease, predicting mortality and response to therapy. Albumin, PT or INR, bilirubin, alanine aminotransferase (ALT) and creatinine levels are important laboratory tests to determine the prognosis index in BCS (Child-Pugh, model for end stage liver disease/MELD, Rotterdam index, New Clichy and BCS-TIPS). Other laboratory examinations are mainly performed to determine the underlying prothrombotic cause. Table 8 described a complete examination to find the underlying prothrombotic cause in BCS. ${ }^{3,4,8}$

\section{Sonography Features in Budd-Chiari Syndrome ${ }^{9-14}$}

The most common imaging modality being used to evaluate BCS consists of ultrasonography (USG), 
coloured Doppler, and other advanced examinations which are equipped with computed tomography (CT) and magnetic resonance imaging (MRI) examination (Figure 1). BCS has various imaging appearance depending on the form of the disease (acute or chronic). In the acute phase of this disease, the liver is enlarged with simultaneous feature of ascites. Sometimes in the liver, the imaging findings vary due to bleeding and infarct. Thrombus in the hepatic vein has various echogenicity which can be seen in the lumen and in the absence of blood flow in coloured Doppler. However, in chronic BCS, the imaging findings may vary, ranging from chronic occlusion of the inferior vena cana and/ or the presence of intrahepatic collaterals (Figure 2). Intrahepatic collaterals, which are observed as small and tortuous are important findings in the imaging of BCS. Caudate lobe is not frequently enlarged because it has separated vein which can cause blood to flow directly to the inferior vena cava. In monophasic wave Doppler, the hepatic vein occlusion or intrahepatic collateral is observed, compared to the triphasic wave in normal hepatic vein due to the radiation of atrial pulsation. (Figure 3). Other imaging appearances are liver fibrosis, nodule regenerative hyperplasia (NRH), cirrhosis and portal hypertension, which are observed as the rough liver structure echogenicity, with protruded splenoportal axis appearance and splenomegaly.

$\mathrm{CT}$ imaging findings consists of hepatomegaly with low contrast uptake in acute disease, while in chronic disease, there could be increased and heterogenous contrast uptake with lower increase in liver peripheral area and strong increase in the middle. The arterial phase imaging in the chronic phase of this disease may show very solid nodular lesion or probably showing less developed area due to arterio-portal shunting and opacification in the portal vein (Figure 4). Imaging of the portal phase may reveal various increase of heterogeneous and spotted pattern which has increased strong uptake in the middle part of the liver which is adjacent to the inferior vena cava and relatively less or none in peripheral area with low contrast uptake is also observed. In the delayed phase, the increasing uptake pattern will become more homogeneous. Nevertheless, the non-opaque shadowing of the hepatic vein does not change in all phases (Figure 5). This is mainly associated with stasis occurring in the portal vein and sinusoids due to the hepatic vein obstruction and occlusion with or without intrahepatic collaterals. In chronic BCS, changes in liver morphology are also seen. Sometimes, nodular regenerative hyperplasia (NRH) is observed as multiple nodules with various sizes ranging from 0.5 to $4.0 \mathrm{~cm}$. This changes occur as a result of arterial blood flow in particular areas due to disorder of the hepatic vein outflow and portal vein perfusion. Thus, this lesion is seen as an uptake in arterial phase and is observed more evidently in portal phase. Hepatocelullar carcinoma (HCC) is the main differential diagnosis for this lesion. A feature that can help to differentiate NRH from $\mathrm{HCC}$ is in NRH there is no increased uptake compared with HCC that may show wash-out contrast in portal phase.

In addition, the acute phase MRI showed liver enlargement with low wave uptake intensity in $\mathrm{T} 1$ phase (breath hold) and equal increased wave uptake in T2 phase (weighted fast spin echo) and happen in the peripheral area. In the chronic form when liver starts to shrink and become fibrotic, various appearances in wave capture intensity can be seen. Similar to CT, in MRI with contrast, there is a decreased uptake in acute phase and various features in chronic BCS. NRH is more hyperintensed in $\mathrm{T} 1$ and iso- or hypointense in liver parenchyma in T2. CT and MRI imaging may help in differentiating inferior vena cava compression due to caudate lobe hypertrophy and occlusion in inferior vena cava in cases with unclear aetiology or USG appearances (Figure 6).
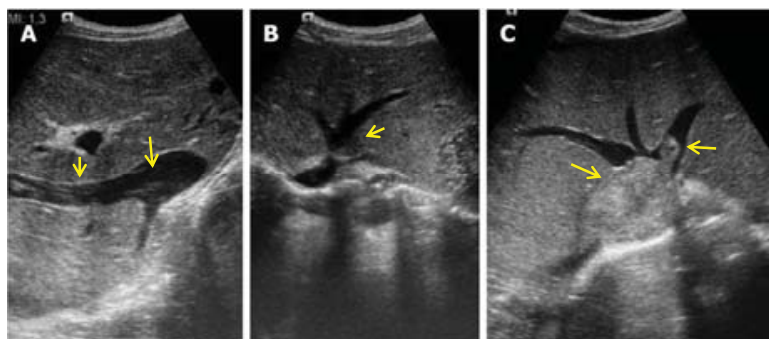

Figure 1. USG Findings: (A) Occlusion of inferior vena cava (IVC); (B) Hepatic venous web causing flow obstruction; (C) Budd-Chiari syndrome due to widening of IVC thrombus arena up to the hepatic vein ${ }^{11}$
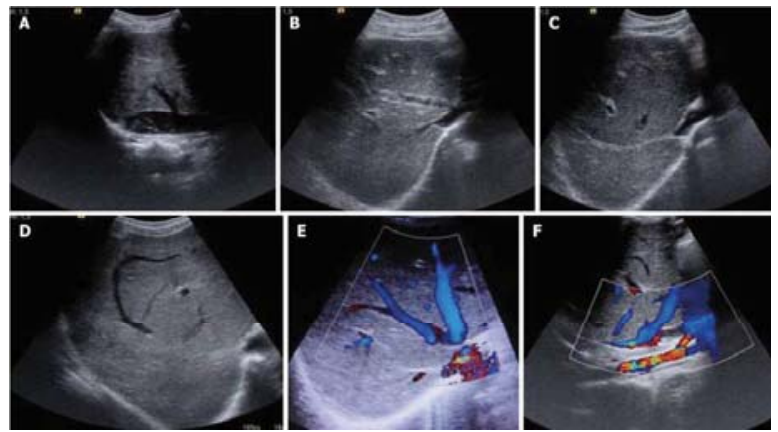

Figure 2. USG (A-D) and doppler Features (E,F):( $A)$ Inferior vena cava web with floating intra-luminal thrombus; (B) Partial hepatic vein thrombus and narrowing of the right hepatic vein osteal; (C) Right hepatic vein fibrosis; (D) Comma shaped collateral; (E,F) Web in the hepatic vein ostium and intrahepatic collateral $^{12}$ 

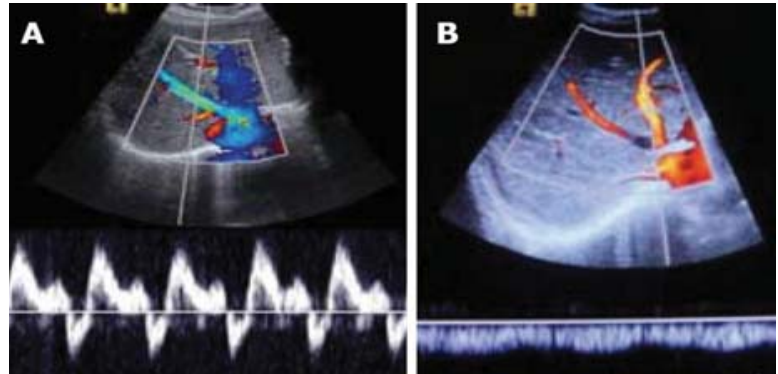

Figure 3. Spectral Doppler results: (A) normal triphase wave in patent hepatic vein; (B) monophasic wave in hepatic vein occlusion $^{13}$
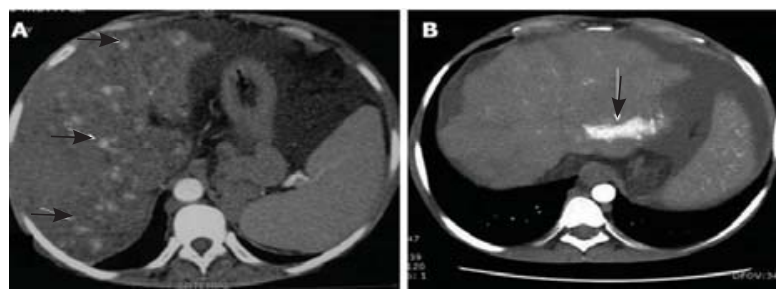

Figure 4. Contrast uptake phase of artery in computed tomography results: (A) Nodular uptake lesion of artery (short arrow) in the background part of Budd-Chiari syndrome which show the presence of regenerative nodular hyperplasia; (B) Other case in chronic Budd-Chiari syndrome. Focal uptake area (long arrow) due to arterio-portal shunting ${ }^{14}$
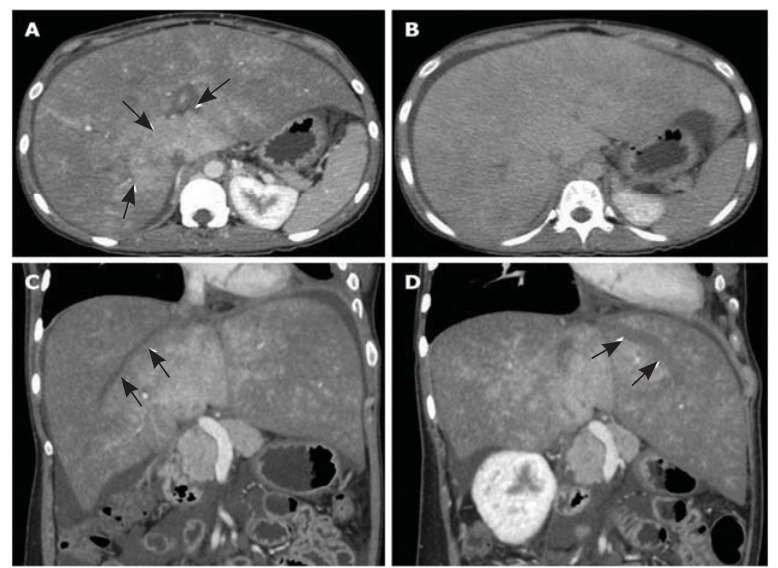

Figure 5. Computed Tomography axial view. Picture of portal vein phase: (A) showing heterogeneity and uptake with spotting pattern and clear or protruding appearance in the center (arrow) which becomes more homogen than the delayed phase; (B). Oblique appearance; (C,D) along the right and left hepatic vein axis showing non-opaque appearance of hepatic vein (arrow) $)^{14}$

\section{MANAGEMENT OF BUDD-CHIARI SYNDROME}

The management of BCS ranges from non-invasive procedures to highly invasive modalities, consisting of medical and recanalization therapy to prevent necrosis. Angioplasty and stenting aim to rapidly decompress sinusoids, so that the hepatic blood flow can be restored. Percutaneous angioplasty using balloon or Gruntzi catheter through femoral or jugular vein can provide better results. Portosystemic shunting; the purpose of side-to-side portosystemic shunting operation is liver decompression. Yet, due to the high perioperative mortality rates, this procedure had been gradually discontinued. Transjugular intrahepatic portosistemic shunt (TIPS) is usually more preferred. TIPS using polytetra fluoro ethylene covered stent (PTFE) could yield in better outcomes. ${ }^{15-17}$

Patients with BCS usually require therapy for ascites and variceal-related conditions. This therapy should be given according to similar management recommendations such as that in ascites and portal hypertension in cirrhosis. ${ }^{18-20}$

BCS patients must receive a long-term anticoagulant therapy as soon as possible to decrease the risk of obstruction caused by clots and new thrombus development episodes. Based on the recommendation for deep vein thrombosis (DVT), low molecular weight heparin (LMWH) is used at least for 5 to 7 days and oral anticoagulant treatment with vitamin $\mathrm{K}$ antagonist (VKA), which aims to achieve Internasional Normalised Ratio (INR) between 2 and 3. LMWH can be discontinued if INR target is not achieved in 2 consecutive measurements..$^{21-23}$
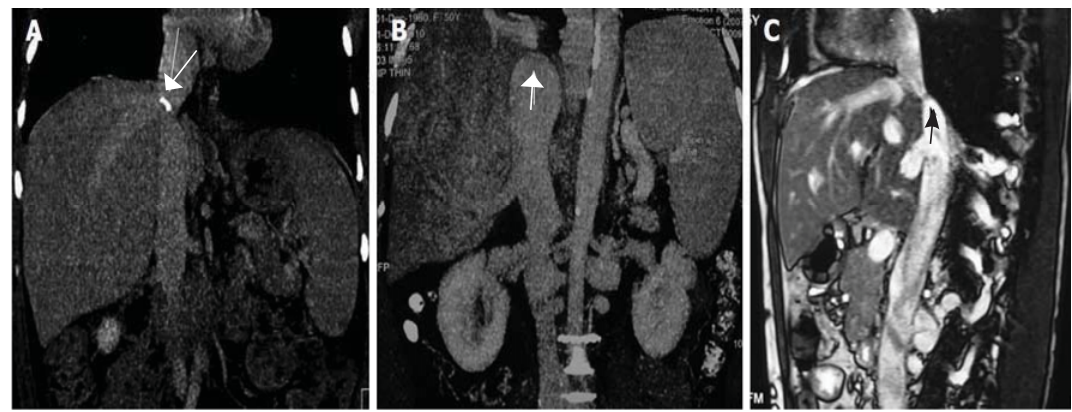

Figure 6. Inferior Vena Cava: $(A, B)$ Computed tomography results (coronal section) showing the presence of calcification (long arrow) and non-calcification of inferior vena cava web (short arrow); (C) MRI T2 weighted Sagital showing the presence of membrane occlusion in inferior vena cava (end of arrow) ${ }^{14}$ 


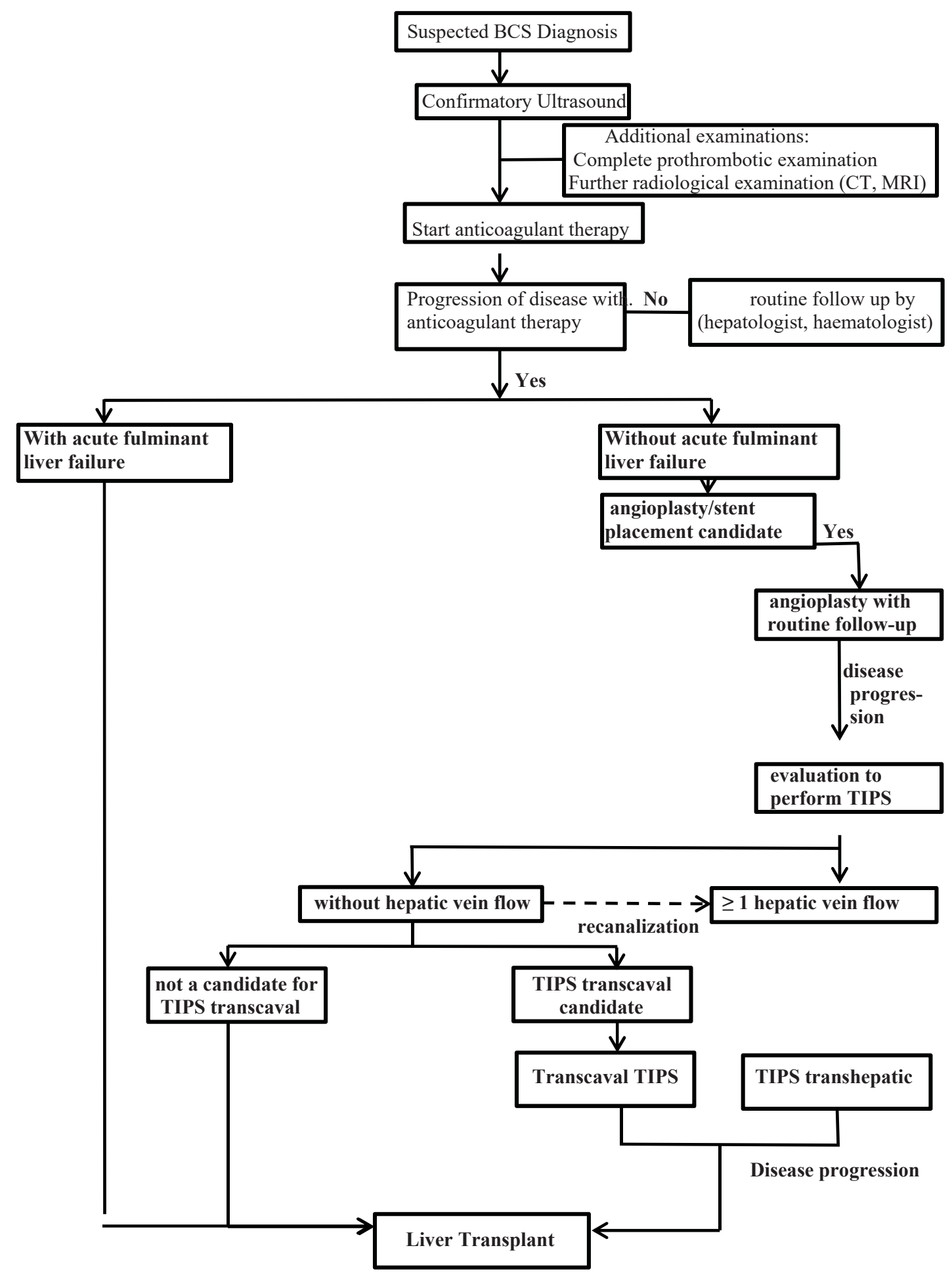

* additional appearance after duplex diagnosis is needed as planned therapy in the future and for discussion with multidisciplinary team (evaluation the possibility of angioplasty, TIPSS or liver transplant). If patients suffered from acute fulminant liver failure (or BCS-TIPSS score $>7$ ), it is recommended to refer immediately for liver transplant, if possible, as the main choice. ${ }^{3}$

* Appropriate for transcaval TIPSS depending on the experience of health centre with transcaval TIPSS. If there is no patent hepatic vein available but thrombus is still fresh or new, hepatic vein recanalization can be suggested, if successful, TIPSS placement can be performed with transhepatic route. CT : computed tomography; MRI : magnetic resonance imaging, TIPS: transjugular intrahepatic portosystemic shunt.

Figure 2. Establishing diagnosis and therapy in patients with Budd-Chiari syndrome (BCS) 


\section{REFERENCES}

1. Hirlan. Sindrom Budd-Chiari: Diagnosis dan Pengelolaan. Semarang Gastroentero-Hepatology update IV 2015;65-70.

2. Martens P, Nevens F. Budd-Chiari Syndrome: United European Gastroenterology Journal 2015;3:489-500.

3. Garcia-Pagan JC. EASL Clinical Practical Guidelines: vascular diseases of the liver. J Hepatol 2016;64:179-202.

4. Bayraktar UD, Seren S, Bayraktar Y. Hepatic venous outflow obstruction:three similar syndromes. World J Gastroenterol 2010;13:1912-27.

5. Aydinli M, Bayraktar Y. Budd-Chiari syndrome: etiology, pathogenesis and diagnosis. World J Gastroenterol 2007;13:2693-6.

6. Valla DC. Primary Budd-Chiari syndrome. J Hepatol 2009;50:195-203.

7. Plessier A, Valla DC. Budd-Chiari syndrome. Semin Liver Dis 2008;28:259-69.

8. Darwish MS, Plessier A, Hernandez-Guerra M. Etiology, management, and outcome of the Budd-Chiari syndrome. Ann Intern Med 2009;151:167-75.

9. Makes D. Ultrasonografi Hati. In: Sulaiman A, Akbar N, Lesmana LA, Noer S, eds. Buku ajar Ilmu Penyakit Hati edisi pertama Jakarta: Sagung Seto 2012

10. Draghi F, Rapaccini GL, Fachinetti C, Matthaeis N, Battaglia S, Abbattista T, et al. Ultrasound examination of the liver: normal vascular anatomy. J Ultrasound 2007;105e11:2017.

11. Amar Mukund, Shivanand Gamanagatti. Imaging and interventions in Budd-Chiari syndrome. World J Radiol 2011;3:169-77.

12. Cai SF, Gai YH, Ma S, Liang B, Wang GC, Liu QW. Ultrasonographic visualization of accessory hepatic veins and their lesions in Budd-Chiari syndrome. Ultrasound Med Biol 2015;41:2091-8.

13. Trivedi CR, Thakkar H, Sannananja B, Shah HU. Ultrasound and Doppler features of Budd-Chiari syndrome. Ultrasound Q 2015;31:45-54.

14. Faraoun SA, Boudjella Mel A, Debzi N, Afredj N, Guerrache Y, Benidir N. Budd-Chiari syndrome: a prospective analysis of hepatic vein obstruction on ultrasonography, multidetectorrow computed tomography and MR imaging. Abdomen Imaging 2015;40:1500-9.

15. Plessier A, Darwish MS, Hernandez Guerra M, Consigny, Febris F. Multicenter follow up study. J Hepatol 2010;51;2108.

16. Raffa S, Reverter JC, Seijo S, Tassies D, Abraldes JG, Bosch J, et al. Hypercoagulability in patients with chronic noncirrhotic portal vein thrombosis. Clin Gastroenterol Hepatol 2012;10:72-78.

17. Tripathi D, Sunderraj L, Vemala V, Mehrzad H, Zia Z, Mangat $\mathrm{K}$, et al. Long-term outcomes following percutaneous hepatic vein recanalization for Budd-Chiari syndrome. Liver Int 2017;37:111-20.

18. Kochar R, Masoodi I, Dutta U, Singhal M, Miglani A, Singh $\mathrm{P}$, et al. Celiac disease and Budd Chiari syndrome. Eur J Gastroenterol Hepatol 2009;21:1092-4.

19. Spaander MC, Hoekstra J, Hanssen BE. Anticoagulant therapy in patient with non-cirrhotic portal vein thrombosis: effect on new thrombosis events and gastrointestinal bleeding. J Thromb Haemost 2013;11:452-459.

20. Plessier A, Rautou PE, Valla DC. Management of hepatic hepatic vascular diseases. J Hepatol 2012;56;S25-S38.
21. Khan F, Rowe I, Martin B, Knox E, Johnston T, Elliot C, et al. Outcomes of pregnancy in patients with known Budd-Chiari syndrome. World J Hepatol 2017;9:945-52.

22. Suharti Catharina, Mika L. Diagnosis and Treatment of Venous Thromboembolism. Perhimpunan Hematologi Dan Transfusi Darah Indonesia. Workshop Semarang 2016.

23. Seijo S, Plessier A, Hoekstra J. Good long-term outcome of Budd-Chiari syndrome with a step-wise management. Hepatology 2013;57:1962-8. 